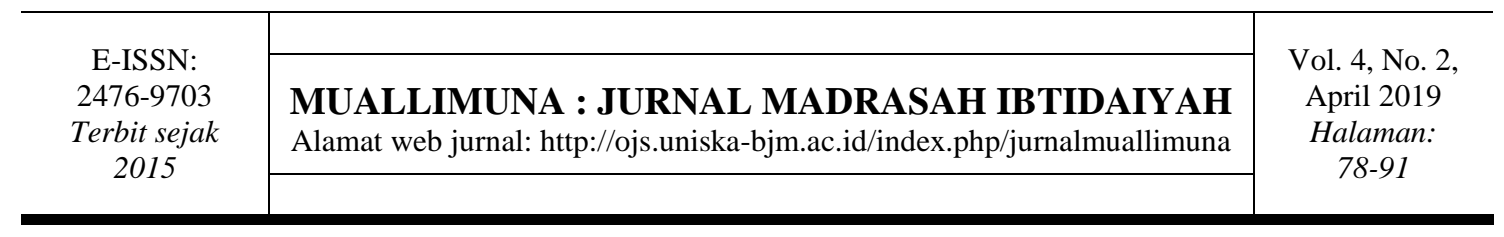

\title{
REFLEKSI GURU DALAM MELAKUKAN PENELITIAN TINDAKAN UNTUK MENINGKATKAN KEBERHASILAN SISWA
}

\author{
Cecep Maman Hermawan \\ PGMI, Universitas Muhammadiyah Jakarta \\ cmh77rumah@gmail.com
}

\begin{abstract}
Abstrak: Latar belakang penelitian ini adalah bahwa penelitian tindakan dan karya ilmiah yang dilaksanakan oleh guru hanya untuk memenuhi tuntutan kedinasan saja, bukan sebagai bagian dari refleksi diri ilmiah guru. Tujuan dari penelitian ini adalah untuk meningkatkan keterampilan penelitian tindakan guru. Metode yang digunakan adalah participatory action research yang terdiri dari diagnosis, tindakan, ukuran, dan refleksi. Berdasarkan temuan di lapangan, para guru akan lebih mudah melakukan penelitian tindakan dengan pola penelitian tindakan kelas yang ditunjukkan oleh peneliti. Sehingga penulisan penelitian tindakan kelas dapat dilakukan dengan baik dan mudah dilaksanakan oleh guru. Disimpulkan bahwa kesan sulitnya penelitian tindakan kelas akan berkurang jika para guru mulai memahami pola metode penelitian tindakan kelas.
\end{abstract}

\section{Kata Kunci: Refleksi Guru; Penelitian Tindakan; Pola Tindakan Refleksi \\ REFLECTION OF TEACHERS IN DOING ACTION RESEARCH TO IMPROVE STUDENT SUCCESS}

\begin{abstract}
The background of this research is that the action research and scientific work carried out by the teacher is only to fulfill the demands of service, not as part of the teacher's scientific self-reflection. The purpose of this study is to improve teacher action research skills. The method used is Participatory Action Research consisting of diagnosis, action, measure, and reflection. Based on the findings in the field, teachers will find it easier to conduct action research with a class action research pattern shown by researchers. So that writing classroom action research can be done well and easily implemented by the teacher. It was concluded that the impression of the difficulty of classroom action research would be reduced if teachers began to understand the pattern of classroom action research methods.
\end{abstract}

Keywords: Reflection of Teacher; Action Research; Pattern of Action Reflection

\section{PENDAHULUAN}

Standar penilaian kinerja guru mulai memasuki babak baru. Ini adalah sisi lain dari konteks perubahan kurikulum yang esensial. Dengan kata lain, pemerintah kita sedang mendorong Guru sebagai Peneliti. Hal ini akan lebih bermakna jika kemampuan dan keterampilan guru meneliti (terutama penelitian tindakan kelas) benar-benar diasah sedemikian rupa. 
Guru sebagai peneliti menjadi awal yang bermakna untuk meningkatkan kinerja guru. Karena, guru meneliti sebagai praktik inti dari refleksi (Dewey, 1933; Lougran, 2010: 161; Schön, 1983; Ashbaker, 2009). dirinya untuk memperbaiki dan meningkatkan kemampuan dan keterampilan dirinya sebagai guru yang profesional. Dan tindakan profesional guru, tentu saja dilaksanakan oleh seorang guru berdasarkan tindakan ilmiah dan terukur, bukan sekedar kebaikan intuitif pribadi atau imajinasi tanpa dasar. Hal ini menimbulkan dampak langsung, yaitu berpengaruh terhadap perbaikan proses pembelajaran anak didik

Kajian guru sebagai peneliti sudah dilaksanakan dalam penelitian seperti Andrea M. Babkie dan Mary C. Provost mengemukakan bahwa dengan undang-undang baru dan akuntabilitas meningkat untuk guru, melakukan penelitian sebagai guru peneliti di kelas sendiri adalah salah satu sarana yang dapat membantu guru meningkatkan keberhasilan siswa dan juga mendokumentasikan intervensi yang efektif (Babkie \& Provost. 2004).

Penelitian lainnya seperti oleh Susan Hill mengemukakan proyek guru sebagai peneliti mengungkapkan bahwa anak-anak, bebas dari batas lokasi geografis, memiliki akses dan dapat menggunakan teknologi informasi yang jauh melampaui harapan guru dan memiliki akses ke peralatan luar yang tersedia di banyak sekolah dan prasekolah. Dalam menanggapi penggunaan anak-anak dari dan keterlibatan dengan kemahiran baru guru-peneliti mengembangkan kerangka kerja yang dikenal sebagai Peta Membaca Ganda. Guru-peneliti menjadi fasilitator dari program pembelajaran profesional yang terjadi di daerah setempat (Hill, 2010). Berdasarkan kajian dari Elliott dan Adelman, Andrea M. Babkie dan Mary C. Provost dan Susan Hill mendorong peneliti untuk ikut serta melakukan kajian seperti mereka melalui Participatory Action Research (PAR) dengan mengajukan penelitian dengan judul "Refleksi Guru Menuju Peningkatan Keberhasilan Siswa."

John Elliott menceritakan pengalamannya sebagai seorang guru di tahun 1960-an. Dia mencoba untuk mematahkan pandangan populer bahwa gerakan guru sebagai peneliti dimulai oleh akademisi dalam sektor pendidikan tinggi. Dalam rangkaian berikutnya guru mengerjakan penelitian dalam masalah praktis dan pada perubahan mendasar atas beberapa aspek pengajarannya. Perkembangan pemahaman sebelumnya diputuskan untuk merubah strategi pengajaran. Dengan kata lain, refleksi memulai tindakan. Melalui evaluasi guru mulai menyadari masalah kemudian dimodifikasi dan berubah. Keputusan untuk menerapkan suatu strategi perubahan sebelumnya terlebih dahulu mengembangkan kesadaran. Tindakan memulai refleksi (Elliot, 2001).

John Elliott memasuki jenjang sebagai dosen dan sebagai peneliti melaksanakan penelitian bersama Clem Adelman dalam Proyek Pengajaran Ford yang disponsori oleh Ford Foundation tahun 1973-1975. Proyek ini melibatkan 40 guru dari 12 sekolah dasar dan menengah untuk melaksanakan penelitian tindakan mengenai masalah penerapan metode discovery dan inquiry di dalam ruang kelas mereka. Penelitian ini menekankan pada bagaimana metode discovery dan inquiry itu diterapkan oleh para guru di kelasnya. Pengumpulan data terutama berdasarkan penelitian tindakan guru dan upaya proaktif mereka dalam mengintervensi kelas. Clem Adelman dan Elliott melibatkan setiap proses triangulasi. Data tersebut berputar di antara para guru, sekolah dan peneliti (Adelman dan Elliott) menetapkan daftar hipotesis diagnostik untuk guru diuji dalam menyoroti datanya masing-masing. Akhirnya, guru bertanya untuk mendapat penjelasan teori pengajaran yang terkandung dalam praktik ruang kelas mereka. Sebagaimana mereka jadi lebih peduli terhadap teori yang telah membimbing pedagogi mereka ketika telah mengumpulkan dan menganalisis data (Elliot, 2001). 
Susan Hill mengemukakan proyek guru sebagai peneliti mengeksplorasi bagaimana anak-anak usia 4-8-tahun memahami dan bekerja dengan bentuk-bentuk baru dari membaca di rumah dan di sekolah. Dua puluh lima guru-peneliti menyelidiki rumah dan sekolah anak-anak berbasis pengetahuan, kemudian direncanakan atau dibuat kurikulum prasekolah berdasarkan temuan. Proyek ini mengungkapkan bahwa anakanak, bebas dari batas lokasi geografis, memiliki akses dan dapat menggunakan teknologi informasi yang jauh di muka harapan guru dan memiliki akses ke peralatan luar yang tersedia di banyak sekolah dan prasekolah. Dalam menanggapi penggunaan anak-anak dari dan keterlibatan dengan kemahiran baru guru-peneliti mengembangkan kerangka kerja yang dikenal sebagai Peta Membaca Ganda (Hill, 2010). Berdasarkan penelitian Susan Hill dikemukakan pelibatan guru sebagai peneliti membuat guru mampu merancang kurikulum dan menjadi fasilitator dari program pembelajaran profesional di wilayahnya.

James McKernan mengemukakan tentang guru sebagai peneliti. Agenda tindakan sosial kita adalah pertama, bahwa semua pendidik memiliki tanggung jawab untuk meneliti. Kedua, kita bisa menawarkan keterampilan profesional melakukan penelitian di dalam sekolah dan lainnya dengan cara-cara tertentu yang mengembangkan gaya-gaya pengajaran yang mempromosikan daripada yang menurunkan derajat penyelidikan, dan yang memajukan gaya guru-kepala sekolah, pengembangan diri dan evaluasi. Universitas bisa dipertimbangkan menetapkan tentu saja dalam penelitian berbasis pengajaran yang mempromosikan keterjalinan universitas-sekolah dan pemahaman staf sekolah sebagai penghargaan para dosen yang akan berbagi secara pribadi, praktis, pengetahuan profesional dalam suatu cara yang sampai sekarang belum terjelajahi (McKernan, 2008: 119-120).

John Dewey dalam bukunya The Sources of a Science of Education, mendiskusikan kemungkinan peranan guru sebagai investigator. Masalahnya adalah lemahnya keterampilan meneliti dan sumber potensial guru sebagai peneliti (Dewey, 1929).

Andrea M. Babkie dan Mary C. Provost mengemukakan bahwa dengan undangundang baru dan akuntabilitas meningkat untuk guru, melakukan penelitian sebagai guru peneliti di kelas sendiri adalah salah satu sarana yang dapat membantu guru meningkatkan keberhasilan siswa dan juga mendokumentasikan intervensi yang efektif (Babkie \& Provost, 2004).

Berdasarkan kajian dan penelitian di atas maka gerakan guru sebagai peneliti harus di dukung dengan komitmen pengajaran dan penelitian sebagai bagian pekerjaan; komitmen untuk pengembangan dan refleksi sebagai makna perbaikan praktik; komitmen untuk mengembangkan komuniti berbagi ceramah pengetahuan teoritis dan praktis dalam tujuan bernilai umum; komitmen untuk menebarkan kebijakan praktis dan hasil penelitian.

Berdasarkan uraian di atas, penelitian ini bertujuan untuk menginvestigasi dan menemukan transformasi profesionalisme guru melalui kegiatan guru sebagai peneliti untuk meningkatkan keberhasilan siswa di kelas. Guru sebagai peneliti merupakan upaya sadar guru untuk meningkatkan keberhasilan siswa di kelas agar mampu menyongsong tantangan masa depan.

Adapun rumusan masalah penelitian ini akan mengacu pada refleksi yang diperkenalkan Ghaye dengan simbol huruf $\mathrm{R}$ besar (Ghaye, 2011). Dalam siklus tersebut terdapat empat pertanyaan yang harus di ajwab, yaitu sebagaimana ditunjukkan oleh gambar 1 berikut. 


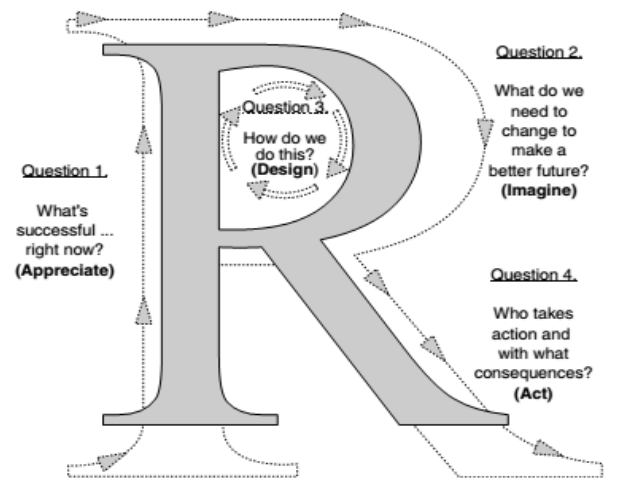

Gambar 1. Kerangka Kerja Reflektif Berbasis Penguatan (Ghaye, et. al. 2008 dalam Ghaye, 2011:18)

Adapun tujuan dari masing-masing pertanyaan yang terdapat pada gambar 1 di atas adalah sebagai berikut.

1) Untuk menghargai (to appreciate). Hal ini terinspirasi oleh Schön (1983) dan Dewey (1933) tentang praktisi reflektif, dan lebih baru-baru ini dengan bekerja pada pertanyaan apresiatif (Cooperrider dan Whitney 2005) dan kecerdasan apresiatif (Thatchenkery dan Metzker 2006). Dalam praktek reflektif lebih berbasis kekuatan adalah niat untuk menghargai dan memahami diri sendiri dan hal lainnya seperti, bakat, keterbatasan, nilai diri, identitas, peran, tanggung jawab dan akuntabilitas. Ini adalah niat untuk mengembangkan pemahaman yang lebih dalam agenda belajar sendiri, rasa diri, pengetahuan diri, kemampuan diri dan tujuan. Tujuannya adalah untuk menggunakan praktek-praktek refleksi untuk memperdalam apresiasi.

2) Untuk membayangkan (to imagine). Tujuannya adalah dengan menggunakan praktek-praktek refleksi untuk menghasilkan, mengelola dan memanfaatkan pengetahuan, membingkai ulang, dan kemudian merekamnya dalam beberapa cara. Tujuannya adalah untuk mendokumentasikan belajar tentang mengajar dan belajar melalui praktek reflektif apa yang berhasil, apa yang perlu diubah dan dengan cara-cara apa - sebagai cara lain untuk meningkatkan praktek.

3) Untuk desain (to design). Niat ini dapat dipengaruhi secara positif oleh niat 1 dan 2. Ini memanfaatkan keahlian individu dan menghubungkan 'pulau inovasi,' membawa keduanya bersama-sama ke keutuhan baru kebijaksanaan kolektif. Kekritisan dan kreativitas diperlukan, bersamaan dengan kesiapan untuk mempertanyakan praktik dan kebijakan keyakinan.

4) Untuk bertindak (to act). Tujuannya di sini adalah untuk melakukan, atau mencapai sesuatu, dengan kolektif ini adalah kebijaksanaan, mengingat bahwa bergerak maju hanya satu pilihan. Apa yang penting adalah bahwa semua yang terlibat mendokumentasikan keputusan yang dibuat dan alasannya bagi mereka (Ghaye, 2011).

Refleksi adalah praktek terampil yang menggunakan proses pengalaman, pengetahuan dan penyelidikan untuk meningkatkan kemampuan kita untuk campur tangan, menafsirkan, dan bertindak positif pada keberhasilan, masalah, dan pertanyaan yang signifikan . Penggunaan praktek reflektif tertentu dapat mengungkapkan wawasan baru dan pemahaman tentang siapa kita dan apa yang kita lakukan. Praktik-praktik ini juga dapat mengungkapkan pilihan, kemungkinan dan jalan untuk tindakan positif dan berkelanjutan. 


\section{METODE}

Metode penelitian ini menggunakan desain Participatory Action Research (PAR) atau penelitian tindakan partisipatori, yaitu suatu proses dinamis untuk pribadi dan pengembangan profesional. Alat ini, mendapat perhatian penuh dari tangan pengurus sekolah, para guru, dan masyarakat mereka, sering menghasilkan emansipasi, melibatkan mitra orang banyak dalam proses pengembangan dan perubahan sekolah (Alana, Milenkiewicz, dan Bucknam. 2008). PAR sebagai alat untuk kepemimpinan bidang pendidikan dengan pendampingan pengembangan organisatoris yang terbaik (Argyris \& Schön, 1974; Coghlan \& Brannick, 2001) dan teori-teori sistem (Senge, 1994) ke dalam suatu alat bermanfaat untuk pendidik yang manyatukan pengembangan program dan evaluasi (Dick, 1998a dalam Alana, Milenkiewicz, dan Bucknam, 2008). Langkahlangkah siklus penelitian tindakan partisipatori adalah sebagai berikut:

1) Diagnosis, mempelajari komuniti atau tim pendidik sebagai kelompok partisipatori untuk mengevaluasi apakah pengetahuan terkini tentang topik sudah dipelajari. Mereka mengemukakan asumsinya tentang topik dan penelitian dan faktor-faktor evaluasi yang memberikan masukan untuk kondisi yang ada, anggota tim meneliti teori dan literatur untuk memahami apakah hal-hal lain telah dilakukan dalam situasi yang serupa.

2) Tindakan, berbasis pada penelitian ini, mereka bekerja secara individu dan dengan kelompok mereka untuk merencanakan kemungkinan ketentuan tindakan dan cara untuk mengukurnya. Dalam semua kasus, rencana mereka adalah terkonsepsikan dengan tujuan menggerakkan kondisi yang ada untuk peningkatan keefektifan.

3) Mengukur, penerapan yang diikuti oleh pengukuran sebagai pekerjaan partisipan untuk mencapai hasil belajar siswa. Guru menggunakan bentuk-bentuk pengukuran ganda dengan apa yang Pengukuran sebagai sumber data kuantitatif, baik dari sisi siswa berupa hasil belajar maupun dari sisi guru berupa ketuntasan pembelajaran berupa mastery learning.

4) Refleksi, Refleksi partisipan individual pada proses mereka, tindakan mereka, dan hasil mereka, diantara satu demi satu dan sebagai kelompok. Selama refleksi ini, mereka juga mengadakan curah gagasan alternatif dan langkah-langkah tambahan. Penelitian PAR termasuk refleksi sebagai sumber data kualitatif melalui bimbingan mereka sebagai proses mereka.

Jika siklus PAR pertama masih belum memenuhi kriteria yang sudah ditentukan oleh individu atau tim guru, maka siklus dilanjutkan. Dan jika siklus PAR sudah memenuhi kriteria, maka penelitian dihentikan.

Data primer merujuk pada aspek pengamatan terhadap guru yang terdiri dari: refleksi kinerja guru berupa apresiasi, membayangkan, rancangan, dan tindakan. Data sekunder adalah berupa pengamatan atas kemampuan perilaku budaya informan dalam

kehidupannya. Sumber data dalam penelitian ini adalah (1) guru-guru di Bekasi dan Tangerang Selatan yang terpilih 3 orang.

Teknik pengumpulan data yang dipakai dalam penelitian ini adalah siklus dari Participatory action research, yaitu: diagnosis, aksi, pengukuran, dan refleksi. 


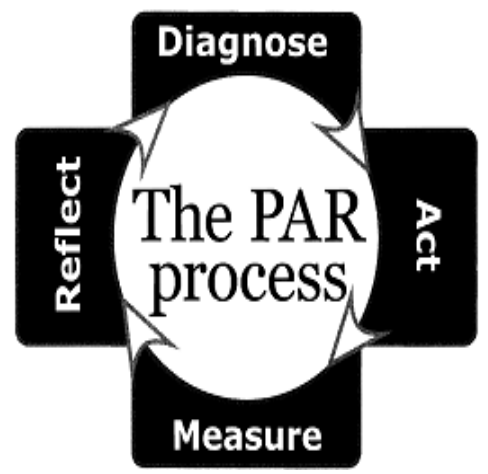

Gambar 2. Siklus Participatory Action Research (PAR)( Alana, Milenkiewicz, dan Bucknam, 2008)

Adapun instrument yang digunakan dalam penelitian ini adalah lembar observasi kegiatan guru dalam melaksanakan penelitian tindakan. Berikut contoh kisi-kisinya.

Tabel 1. Kisi-kisi Lembar Pengamatan Participatory Action Research

\begin{tabular}{|c|c|c|c|}
\hline $\begin{array}{l}\text { No } \\
\cdot\end{array}$ & $\begin{array}{c}\text { ASPEK } \\
\text { SEGI PENELITIAN GURU }\end{array}$ & YA & TIDAK \\
\hline 1. & $\begin{array}{l}\text { Pertanyaan Penelitian: } \\
-\quad \text { Pertanyaan Penelitian Guru }\end{array}$ & & \\
\hline 2. & $\begin{array}{l}\text { Studi-studi Awal: } \\
\text { - } \quad \text { Sumber literatur utama }\end{array}$ & & \\
\hline 3. & $\begin{array}{l}\text { Variabel Unsur-unsur yang akan Diukur: } \\
\text { - } \quad \text { Isi pembelajaran } \\
\text { - } \quad \text { Langkah-langkah Pembelajaran } \\
\text { - } \quad \text { Keterampilan pembelajaran siswa }\end{array}$ & & \\
\hline 4. & $\begin{array}{l}\text { Pengukuran Lokal: } \\
-\quad \text { Observasi guru } \\
-\quad \text { Hasil belajar siswa } \\
-\quad \text { Dokumentasi }\end{array}$ & & \\
\hline 5. & $\begin{array}{l}\text { - } \quad \text { Produk pembelajaran dengan penjelasan siswa } \\
\text { Bentuk Analisis: } \\
\text { - } \quad \text { Analisis kualitatif } \\
\text { - } \quad \text { Analisis kuantitatif }\end{array}$ & & \\
\hline
\end{tabular}

Adapun teknis analisis data penelitian ini adalah mengikuti rumus berikut:

$\mathrm{NA}=$ Jumlah Skor yang Dicapai $\times 100 \%$ Jumlah Skor Maksimum

Apabila semua indikator yang ditetapkan sudah memenuhi ketuntasan (mencapai rata-rata kelas minimal $80 \%$ dan maksimal 100\%) maka dapat diinterpretasikan bahwa hasil participatory action research guru meningkat. 


\section{HASIL DAN PEMBAHASAN \\ Hasil}

Adapun hasil penelitian ini berdasarkan siklus kerangka kerja reflektif adalah sebagai berikut:

\section{Menghargai (to appreciate)}

Guru yang merefleksi dirinya atas bakat, keterbatasan, nilai diri, identitas, peran, tanggung jawab dan akuntabilitas sebagai guru kelas. Peneliti mengingatkan kembali teman-teman guru bahwa refleksi diri tidak selalu harus mengingat kekurangan diri saja, namun melihat diri guru sebagai professional yang yakin telah banyak berkiprah di dunia pendidikan dan menjadi pematik keberhasilan anak-anak muda yang ingin mengukir prestasi dimasa yang akan datang.

Proses penyadaran diri ini adalah proses brain storming peneliti bersama guru untuk mulai menggali berbagai potensi tersembunyi guru yang dapat dimunculkan ketika para guru memang memerlukannya, terutama dalam proses penelitian tindakan kelas. Peneliti mendorong penyadaran diri guru secara seimbang, baik sisi kelebihan diri guru maupun sisi kelemahan diri guru sebagai professional di sekolah. Peneliti bertanya kepada beberapa guru akan peran penting mereka di dalam kelas dan potensi-potensi apa yang kiranya dapat menjadi batu loncatan guru yang bersangkutan untuk meningkatkan profesionalisme dirinya.

Peneliti mengajukan beberapa hal yang bersifat teknis. Peneliti meminta para guru untuk mengingat kembali apa yang dipikirkan oleh guru untuk mempersiapkan diri dalam membuat rancangan pelaksanaan pembelajaran. Rancangan pelaksanaan pembelajaran bisa dijadikan bahan dasar untuk terjadinya proses perbaikan. Proses perbaikan bisa dimulai dari indicator, model atau metode pembelajaran, langkah-langkah pembelajaran dan penilaian pembelajaran, baik penilaian autentik maupun penilaian akhir tertulis. Perbaikan-perbaikan dalam ruang lingkup rancangan pelaksanaan pembelajaran bisa berlanjut pada media pembelajaran yang mendukung penuh semua proses pembelajaran dari awal sampai pembelajaran selesai/tuntas.

Pelaksanaan pembelajaran pada umumnya terjadi di dalam kelas cenderung pada guru yang menerangkan materi. Guru kemudian membuat umpan balik dan akhirnya dibuatlah kesimpulan materi pembelajaran. Guru yang sudah menyelesaikan pembelajaran pada bagian tertentu akan memberi pertanyaan atau ulangan harian yang bertujuan untuk mengetahui keberhasilan siswa dalam proses pembelajaran yang sedang berlangsung. Namun pada umumnya ulangan harian diselenggarakan guru setelah satu kompetensi dasar telah diselesaikan. Di lapangan uji kompetensi siswa dalam bentuk ulangan sudah biasa dilakukan. Namun penilaian selama pembelajaran berlangsung sebagian tidak atau belum tercatat. Dan guru terkadang belum menulis rubriknya. Sehingga tidak jelas pengukuran kemampuan kompetensi tertentu siswa, meskipun dinyatakan dalam penilaian selama pembelajaran (authentic assessment) berlangsung.

\section{Membayangkan (to imagine)}

Berdasarkan temuan berikutnya adalah bahwa guru sudah mulai merefleksi dirinya. Guru mulai mengemukakan bahwa salah satu pihak dari terjadinya permasalahan di dalam kelas adalah dari pihak diri guru, selain pihak siswa. Namun, ternyata guru belum bisa menguraikan permasalahan tersebut secara rinci. Guru dalam merefleksi dirinya sering mengemukakan permasalahannya dengan istilah-istilah yang abstrak. Misalnya, guru dengan mudah mengemukakan bahwa salah satu permasalahan di 
kelasnya adalah akibat guru yang mengajar secara "monoton, konvensional, tradisional, dan istilah-istilah absrak serupa. Secara umum memang bisa saja dikatakan benar, namun dalam konteks ilmiah kata-kata tersebut terlalu menyederhanakan fakta lapangan. Masalahnya kata-kata tersebut sering diangkat dalam konteks refleksi diri guru yang memasuki jenjang kegiatan ilmiah seperti penelitian tindakan kelas. Sehingga berdasarkan tulisan tersebut seakan-akan guru yang bersangkutan tidak menyadari bahwa pernyataannya tersebut justru dilakukan oleh dirinya sendiri. Guru secara lugas menunjukkan ketidakprofesionalan dirinya tanpa suatu konfirmasi.

Berdasarkan kedua temuan di atas, peneliti menganggap guru belum menyadari bahwa menyampaikan kelemahan siswa maupun dirinya sebagai guru sering menggunakan kata-kata atau kalimat-kalimat yang terlalu disederhanakan dan tidak melakukan konfirmasi berdasarkan fakta. Alih-alih, menguraikan masalah berdasarkan fakta alamiah, penyederhanaan tulisan guru ini justru lebih menunjukkan kelemahan diri guru dalam melakukan refleksi diri tertulis secara ilmiah. Hal ini jelas merugikan, baik diri siswa maupun diri guru itu sendiri. Karena para pembaca akan memberi penilaian lebih buruk daripada kenyataan fakta lapangan ruang kelas.

Berdasarkan data lapangan, ada guru yang mengungkapkan permasalahan dalam refleksi diri guru sudah sedikit lebih menukik. Misalnya, guru mengemukakan bahwa guru dalam pembelajaran selalu menggunakan pembelajaran "ceramah" saja. Berdasarkan pernyataan ini, alih-alih memberikan keterangan yang lebih menukik, justru memunculkan pertanyaan. Hal ini, dikarenakan apakah benar kegiatan guru pasti ceramah saja? Memang jika merujuk model pembelajaran ceramah (Arends, 2012. Learning to Teach, bab 7) terdapat empat langkah pembelajaran ceramah, yaitu: menyampaikan tujuan dan persiapan pembelajaran, Advanced Organizer (di Indonesia sering menggunakan istilah apersepsi), menyampaikan materi secara terurut dan tuntas, dan terakhir melakukan umpan balik. Berdasarkan model pembelajaran tersebut peneliti biasanya akan mempertanyakan kalau memang ceramah, apa saja langkah-langkahnya? Jawaban dari guru tidak sistematis dan berurut. Pernyataan guru lebih banyak menggunakan perasaan dan pengalaman yang biasa mereka lakukan, bukan berdasarkan sumber literatur yang dapat dipertanggungjawabkan tingkat keilmiahannya. Ketidakilmiahan pernyataan tertulis ini bisa saja menjadi boomerang bagi guru itu sendiri. Guru sering mendapat penilaian ironis sebagai pekerja professional yang tidak bekerja secara professional. Permasalahan ini menunjukkan permasalahan berawal dari proses guru memperoleh gelar sarjana pendidikan. Bagaimana materi-materi kuliah dan internalisasi proses perkuliahan pendidikan membentuk mahasiswa menjadi pendidik professional berbasis kompetensi dan keterampilan yang dapat dipertanggungjawabkan secara ilmiah. Masalah ini perlu dibahas dalam penelitian lain yang lebih intensif.

Karena penelitian yang dilakukan oleh peneliti adalah penelitian tindakan partisipatori, sehingga peneliti berkewajiban melakukan emansipasi untuk memperbaiki kondisi semula. Mendorong guru untuk menghindarkan diri dari penyataan-pernyataan yang terlalu menyederhanakan masalah dengan kalimat-kalimat atau kata-kata abstrak.

Guru yang melakukan refleksi diri sering terlihat kesulitan jika dipertanyakan mengenai permasalahan dirinya di dalam kelas. Guru sesungguhnya melakukan refleksi diri dengan membuat catatan-catatan harian yang ditulis secara ilmiah. Jika merujuk pada buku Barbara Ann Nilsen, bahwa terdapat 15 cara mengamati siswa secara kuantitatif maupun kualitatif untuk menjadi catatan refleksi diri guru (Nilsen, 2010). Catatan-catatan ini bisa mengungkapkan kondisi pembelajaran dan siswa-siswa di dalamnya, termasuk peranan guru. Catatan-catatan ini sebenarnya bersifat authentic karena dilakukan ketika 
peristiwa terjadi (running record atau pemanfaatan teknologi berupa audio dan video record).

\section{Tindakan Kinerja Guru}

Proses kegiatan refleksi diri lainnya bisa dimulai dengan kegiatan persiapan pembelajaran. Berdasarkan data lapangan guru sering mengemukakan bahwa yang termasuk dalam persiapan pembelajaran adalah membuat rancangan pelaksanaan pembelajaran, menyiapkan media pembelajaran, materi pembelajaran dalam bentuk buku ajar dan buku pendamping atau pendukung materi kajian siswa. Persiapan pembelajaran guru lainnya biasanya mengamati dan pendalaman atas kurikulum yang berlaku dan silabus. Sebagian besar kurikulum dan silabus sudah ditetapkan oleh kementerian dalam bentuk peraturan menteri. Kebebasan peran guru sebenarnya semakin terbuka, namun sering berakhir pada penyerahan penentuan kurikulum kepada pihak pemerintah. Hal ini ditengarai dengan praanggapan awal bahwa sebagian besar guru belum mampu merancang sendiri kurikulumnya meskipun nama kurikulum menunjukkan kemandirian kurikulum. Dalam kurikulum tahun 2013 isi kurikulum dinilai lebih terinci dan guru hanya menjalankan kegiatan pembelajaran mengikuti petunjuk teknis yang sudah ditentukan oleh pemerintah. Tingkat rincian ini ternyata membuat kesulitan tersendiri terhadap guru. Kesiapan prosedur pembelajaran yang ditentukan pemerintah dianggap menjadi keberlimpahan produk kinerja guru yang sulit dipenuhi oleh setiap guru. Sekarang memasuki kurikulum nasional yang dianggap sebagai kurikulum penyempurnaan kurikulum sebelumnya. Terpenting bagi guru, apapun kurikulumnya, kreativitas guru dalam proses pembelajaran tetap menentukan keberhasilan keberlangsungan pembelajaran.

Selain rancangan pelaksanaan pembelajaran, perencanaan pembelajaran guru dimulai dengan membaca. Membaca materi siswa dan materi-materi yang diperluas dari kajian utama tersebut. Kedua, memahami siswa, hal ini penting karena guru yang mengenal siswalah yang dapat mengajar, mengukur kemampuan siswa dan dapat memberi pembelajaran yang mampu dilaksanakan siswa. Ketiga, membuat tugas untuk siswa, tugas pembelajaran berbeda dengan menguji kemampuan hasil belajar siswa. Tugas pembelajaran adalah tugas siswa yang merupakan bagian dari model pembelajaran. Keempat, membuat dugaan bahwa siswa mampu melaksanakan tugas yang dibuat oleh guru. Hal ini penting agar guru tidak memberikan tugas di luar kemampuan siswa. Kelima, guru membuatkan prosedur dan aturan kinerja siswa agar siswa mampu mengerjakan tugas dengan baik. Keenam, guru melaksanakan kegiatan tertentu sebelum belajar. Kegiatan ini bisa berupa berbagai kegiatan yang merupakan persiapan siswa dan guru yang akan memulai pembelajaran. Ketujuh, guru melaksanakan kegiatan selama pembelajaran berlangsung. Kedelapan, guru melaksanakan kegiatan setelah pembelajaran berlansung. Kesembilan, guru menuliskan berbagai persiapan tersebut dalam bentuk rancangan pelaksanaan pembelajaran. Kesembilan kegiatan perencanaan pelaksanaan pembelajaran guru banyak yang luput dilakukan oleh guru. Sehingga proses perencanaan yang kurang terukur menimbulkan permasalahan pada ranah pelaksanaan pembelajaran dan penilaian.

Memasuki ranah model pembelajaran dan langkah-langkah pembelajaran, menunjukkan rencana pelaksanaan pembelajaran siapa yang digunakan. Umumnya berdasarkan rencana pelaksanaan pembelajaran dari dinas memuat pendekatan, model, dan metode. Biasanya sering tertera pendekatan contekstual dengan model atau metode cermah, Tanya jawab, dan diskusi. Kemudian, memasuki langkah-langkah pembelajaran dimulai dengan kegiatan awal terdiri dari: salam, berdoa, membuka pembelajaran, dan 
appersepsi. Kegiatan inti tertulis berbagai kegiatan seperti ceramah, Tanya jawab, diskusi, dengan uraian yang lebih terincikan, dan ditutup dengan kesimpulan berdasarkan pembelajaran atau menguji kemampuan siswa. Terakhir adalah kegiatan penutup yang terdiri dari kesimpulan, penutup, dan salam penutup. Secara umum demikian dengan beberapa variasi.

Berdasarkan model pembelajaran dan langkah-langkah pembelajaran ada juga yang sudah mulai mengemukakan model pembelajaran tertentu dengan menyebutkan suatu model tertentu dengan langkah-langkah pembelajaran di dalamnya sesuai dengan langkah-langkah dalam teori model-model pembelajaran.

Memasuki penilaian pembelajaran biasanya dapat dibagi dalam dua kegiatan, pertama adalah penilaian selama pembelajaran berlangsung dan penilaian setelah pembelajaran berlangsung. Yang pertama dilaksanakan ketika pembelajaran berlangsung disebut authentic assessment dan yang terakhir sering disebut tes ulangan harian atau tes formatif.

\section{Merefleksi Tindakan}

Berikut ini adalah tahapan tindakan dari guru-guru yang melakukan penelitian tindakan kelas sebagai berikut

Kasus guru X, Tindakan perbaikan pembelajaran telah selesai dilaksanakan dengan menggunakan metode CTL (Contextual Teaching and Learning). Dengan menggunakan metode ini pesan pembelajaran lebih cepat diterima oleh siswa, karena para siswa mendapat pengalaman langsung dan dapat memadukan antara materi pembelajaran dengan pengalaman yang ada pada diri mereka masing-masing.

Guru masih melanjutkan untuk memberikan bimbingan kepada siswa yang mendapat hasil dibawah KKM denga pembelajaran khusus.

Tabel 2. Lembar Pengamatan Participatory Action Research (guru X)

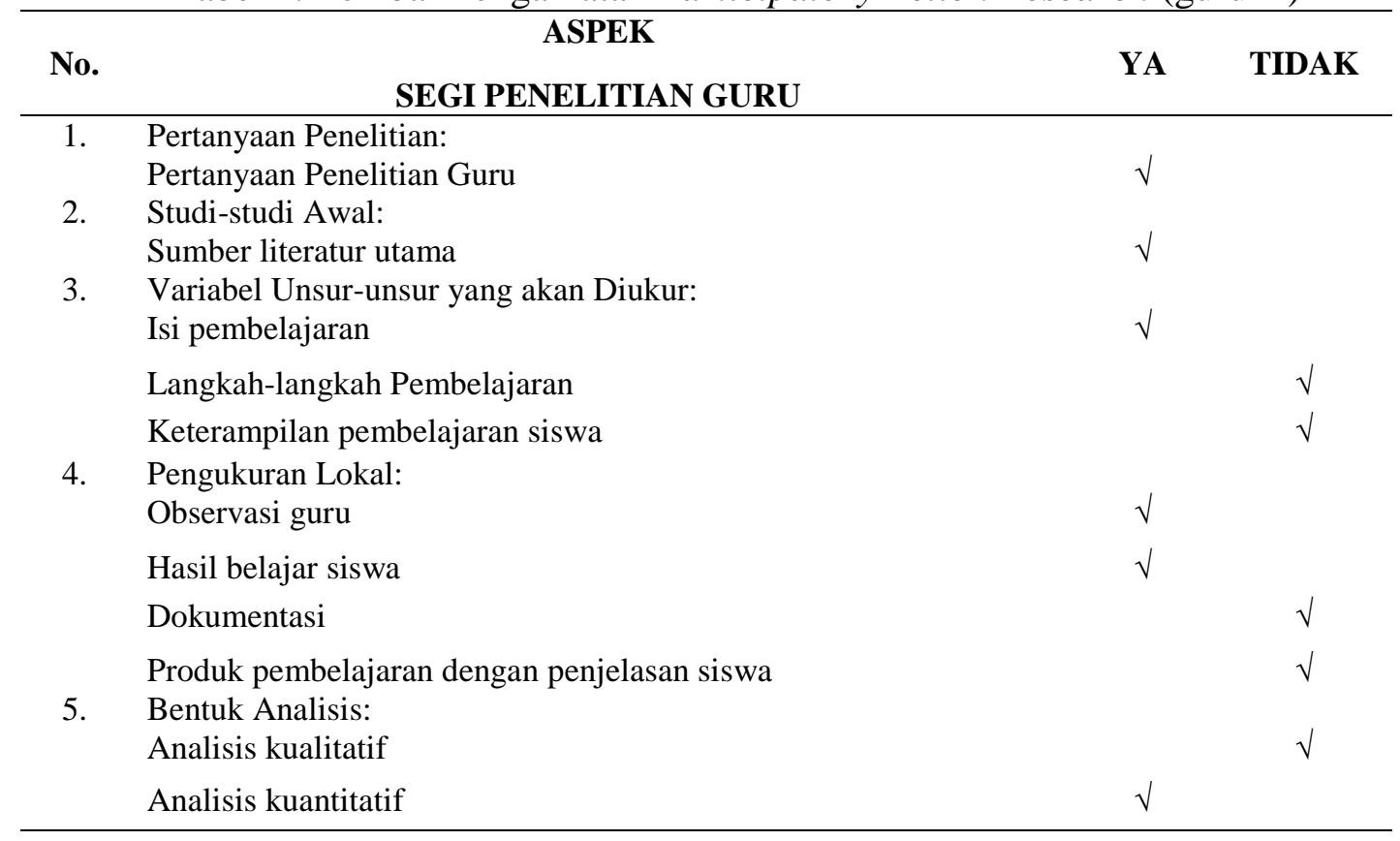

Kasus guru Y, Perbaikan yang akan dilakukan adalah lebih meningkatkan pendekatan terhadap siswa dan perlu di tambah media yang lebih konkrit agar peserta didik dapat mudah menguasai materi yang diajarkan. Semua temuan yang diperoleh di diskusikan dengan teman sejawat dan dijadikan acuan untuk langkah selanjutnya. 
Tabel 3. Lembar Pengamatan Participatory Action Research (guru Y)

\begin{tabular}{|c|c|c|c|}
\hline No. & $\begin{array}{cc}\text { ASPEK } \\
\text { SEGI PENELITIAN GURU } \\
\end{array}$ & YA & TIDAK \\
\hline 1. & $\begin{array}{l}\text { Pertanyaan Penelitian: } \\
\text { - Pertanyaan Penelitian Guru }\end{array}$ & $\sqrt{ }$ & \\
\hline 2. & $\begin{array}{l}\text { Studi-studi Awal: } \\
-\quad \text { Sumber literatur utama }\end{array}$ & $\sqrt{ }$ & \\
\hline 3. & $\begin{array}{l}\text { Variabel Unsur-unsur yang akan Diukur: } \\
\text { - Isi pembelajaran }\end{array}$ & $\sqrt{ }$ & \\
\hline & $\begin{array}{ll}- & \text { Langkah-langkah Pembelajaran } \\
\text { - } & \text { Keterampilan pembelajaran siswa }\end{array}$ & $\sqrt{ }$ & $\sqrt{ }$ \\
\hline 4. & $\begin{array}{l}\text { Pengukuran Lokal: } \\
-\quad \text { Observasi guru }\end{array}$ & $\sqrt{ }$ & \\
\hline & - Hasil belajar siswa & $\sqrt{ }$ & \\
\hline & - Dokumentasi & & $\sqrt{ }$ \\
\hline 5. & $\begin{array}{l}\text { - Produk pembelajaran dengan penjelasan siswa } \\
\text { Bentuk Analisis: } \\
\text { - Analisis kualitatif }\end{array}$ & $\sqrt{ }$ & $\sqrt{ }$ \\
\hline & - Analisis kuantitatif & $\sqrt{ }$ & \\
\hline
\end{tabular}

Kasus Ibu T. Berdasarkan analisis data hasil belajar yang telah dilakukan, dengan demikian dapat di simpulkan bahwa terdapat peningkatan hasil belajar yang lebih baik, setelah dilakukan tindakan pada siklus II dibandingkan pada siklus I. Presentase hasil belajar setelah dilakukan tindakan pada siklus II sebesar 85,24\%, sedangkan presentase pada siklus I sebesar $65,8 \%$.

Tabel 4. Lembar Pengamatan Participatory Action Research

\begin{tabular}{llll}
\hline \multicolumn{1}{c}{ ASPEK } & \multicolumn{1}{c}{ SEGI PENELITIAN GURU } & YA & TIDAK \\
\hline No. & \multicolumn{1}{c}{ Pertanyaan Penelitian: } \\
1. & $\quad$ Pertanyaan Penelitian Guru & $\sqrt{ }$ \\
$2 . \quad$ Studi-studi Awal: & $\sqrt{ }$ \\
$3 . \quad$ Variabel Unsur-unsur yang akan Diukur: & $\sqrt{ }$ \\
& $-\quad$ Isi pembelajaran & $\sqrt{ }$ \\
& $-\quad$ Langkah-langkah Pembelajaran & $\sqrt{ }$ \\
$4 . \quad$ Pengukuran Lokal: & $\sqrt{ }$ \\
& $-\quad$ Observasi guru & $\sqrt{ }$ \\
& $-\quad$ Hasil belajar siswa & $\sqrt{ }$ \\
& $-\quad$ Dokumentasi & $\sqrt{ }$ \\
$5 . \quad$ Bentuk Analisis: & $\sqrt{ }$ \\
& $-\quad$ Analisis kualitatif & $\sqrt{ }$ \\
\hline
\end{tabular}




\section{Ibu X}

\section{Pembahasan}

Guru pertama (ibu X) yang melakukan penelitian tindakan kelas setelah ditelaah berdasarkan lembar pengamatan participatory Acton Research. Penelitian ibu X membuat pertanyaan penelitian dalam bentuk perumusan penelitian di bab pertama. Sumber literatur yang mendukung penelitiannya terdapat pada bab dua menggunakan berbagai sumber tentang contextual teaching and learning. Peneliti banyak memberi masukan-masukan agar sumber literatur ibu X tidak keluar dari zona teknis penelitian tindakan.

Isi pembelajaran yang terdapat di rencana pelaksanaan pembelajaran terungkap metode pembelajaran mulai dari ceramah diskusi sampai menguji pembelajaran. Namun langkah-langkah pembelajarannya jadi lebih bersifat sporadis dan tidak mengikuti langkah-langkah pembelajaran tertentu berdasarkan literatur tertentu. Langkah-langkah pembelajaran yang mengikuti pola pembelajaran yang umumnya cenderung berpusat pada guru, sehingga keterampilan pembelajaran siswa kurang terlihat dapat di kembangkan secara maksimal.

Penelitian tindakan kelas yang dilaksanakan oleh ibu $\mathrm{X}$ tentu saja melakukan pengamatan secara lokal. Lembar pengamatan yang diberikan kepada pengamat dan sudah diisi berdasarkan proses dan keadaan pembelajaran. Pengamat memberikan masukan-masukan yang menunjukkan manakah kegiatan guru yang sudah sesuai atau belum sesuai aturan yang telah ditentukan sebelumnya. Kegiatan pembelajaran guru dalam penelitian ini diakhiri dengan penilaian guru terhadap siswa. Catatan penilaian ibu $\mathrm{X}$ tampilkan dalam penelitiannya.

Penelitian ibu X belum terdokumentasi dengan baik. Foto-foto yang ditampilkan hanya guru, pengamat dan siswa tanpa menampilkan foto sesuai tahapan pembelajaran yang berlangsung.

Produk pembelajaran siswa dan presentasi siswa tidak terlihat karena pembelajaran memang menggunakan pendekatan contextual teaching and learning tapi produk siswa belum ditekankan. Siswa cenderung diuji belum memasuki tahap memiliki produk pembelajaran yang bisa dipresentasikan siswa. Namun mengemukakan jawaban atas lembar kerja siswa sesuai apa yang telah disiapkan oleh guru.

Penelitian tindakan kelas ibu X lebih menekankan data-data angka dalam bentuk nilai siswa sedangkan data kualitatif yang menerangkan proses pembelajaran secara detil kurang dimunculkan oleh peneliti. Sehingga isi penelitian tindakan kelas terkesan penelitian kualitatif dari pada metode campuran (kuantitatif dan kualitatif).

\section{Ibu Y}

Guru kedua (ibu Y) yang melaksanakan penelitian tindakan kelas telah diamati dengan menggunakan lembar pengamatan participatory action research. Ibu Y membuat pertanyaan penelitiannya dalam bab I menggunakan istilah perumusan masalah. Sumber literatur utama yang diajukan oleh ibu Y adalah teori tentang media konkret dengan metode ceramah, tanya jawab, presentasi, dan pemberian tugas. Namun ibu Y kurang memperhitungkan, bahwa dasar teori tulisannya masih lemah dalam konteks praktis. Namun langkah-langkah pembelajaran yang akan dilaksanakan ibu Y ternyata mengikuti langkah-langkah pembelajaran seperti pada rancangan pelaksanaan pembelajaran.

Proses perbaikan pembelajaran penelitian tindakan kelas ini dicantumkan pula nilai hasil belajar siswa, baik pada siklus pertama maupun siklus berikutnya. Namun berdasarkan pengamatan peneliti, ibu Y mencantumkan foto hanya pada bagian-bagian 
tertentu saja. Foto yang muncul hanya guru yang sedang menerangkan. Hal ini sudah mendekati, namun belum sesuai dengan yang diharapkan dalam participatory action research. Ibu Y, dalam proses pembelajarannya membuatkan bahan untuk menjadi produk pembelajaran siswa dan siswa diminta untuk melaksanakan presentasi di depan kelas.

Data yang dikemukakan oleh ibu Y masih hanya memaparkan data-data yang bersifat kuantitatif daripada data yang bersifat kualitatif. Tidak banyak hal yang bisa diungkapkan dalam data dan pembahasan penelitian tindakan kelas ibu Y. Namun yang jelas ibu Y menunjukkan bahwa terjadi perbaikan selama proses pembelajaran maupun hasil pembelajaran siswa selama penelitian tindakan kelas berlangsung.

\section{Ibu T}

Penelitian tindakan kelas yang dilaksanakan oleh ibu T tergolong paling lengkap daripada penelitian tindakan kelas lainnya. Ibu T, melaksanakan penelitian dan diamati oleh peneliti dengan mengunakan lembar pengamatan participatory action research. Hasilnya sangat menarik, karena seluruh aspek pengamatan telah dilaksanakan oleh ibu $\mathrm{T}$.

Pertanyaan penelitian ibu $\mathrm{T}$ dikemukan dalam rumusan masalah di bab I. Bab II ibu $\mathrm{T}$ mengemukakan tinjauan pustaka yang salah satunya menguraikan penjelasan tentang model pembelajaran kooperatif yang lengkap. Hal ini terlihat dari lembar pengamatan pada guru sudah mencantumkan seluruh rangkaian langkah-langkah pembelajaran dari awal sampai akhir pembelajaran dengan model pembelajaran kooperatif.

Penelitian tindakan kelas ini berusaha untuk memperbaiki materi pembelajaran IPA pada siswa kelas dua. Materi pembelajaran ini mengikuti prosedur langkah-langkah pembelajaran kooperatif. Karena pembelajaran kooperatif termasuk dalam kategori pembelajaran yang berpusat pada siswa, maka tentu saja ada tuntutan keterampilan pembelajaran yang harus dimiliki siswa dan menggunakan tes langsung terhadap keterampilan yang dimaksud. Dalam hal ini ibu T menggunakan rubric keterampilan bekerja sama di antara siswa.

Dalam proses penelitian tindakan kelas perlu kiranya dilengkapi dengan beberapa dokumen pendukung yang mengunkapkan bahwa proses pembelajaran berlangsung setahap demi setahap secara terinci dan terdokumentasi dalam bentuk gambar foto berdasarkan gambaran proses tahapan pembelajaran. Hal ini menjadi penting agar pembaca dapat melihat setiap proses pembelajaran secara visual dan dapat dibayangkan sebagai gambaran proses sebenarnya yang terjadi. Sebagai bagian dari proses pembelajaran yang berpusat pada siswa, produk pembelajaran atau hasil kerja siswa yang dipresentasikan dan/atau yang dipamerkan menjadi bagian yang tidak bisa dilepaskan dalam pembelajaran kooperatif.

Penelitian tindakan kelas ibu $\mathrm{T}$ menyajikan analisis kuantitatif dan analisis kualitatif secara seimbang memberi gambaran yang menyeluruh tentang proses pembelajaran di satu sisi dan hasil pembelajaran di sisi yang lainnya. Dengan demikian para pembaca tidak hanya sekedar tahu bahwa ada perbaikan dalam bentuk angka-angka saja. Lebih daripada itu pembaca disajikan suatu rangkaian proses maju bertahap sehingga perubahan atau perbaikan hasil belajar terlihat logis dan praktis bisa ditiru sebagai referensi yang dapat dipertanggungjawabkan secara praktis maupun ilmiah.

Jadi berdasarkan ketiga penelitian tindakan kelas yang dilaksanakan oleh tiga orang guru di atas menunjukkan bahwa persiapan dan proses penelitian yang baik perlu dilakukan 
untuk memperoleh hasil penelitian tindakan kelas yang baik.

\section{PENUTUP}

Berdasarkan penelitian tindakan kelas yang dilaksanakan oleh tiga orang guru, menunjukkan bahwa persiapan dan proses penelitian yang baik perlu dilakukan untuk memperoleh hasil penelitian tindakan kelas yang baik. Terpenting dari penelitian tindakan kelas ini adalah si peneliti dapat memiliki pola-pola dalam rangkaian penelitian tindakannya. Sehingga di lain waktu, jika ingin meneliti penelitian tindakan kelas akan lebih mudah dilaksanakan. Bahkan jika dokumentasinya menggunakan video pun bukan menjadi hal yang sulit.

\section{DAFTAR PUSTAKA}

Ann Nilsen, Barbara. (2010). Week by Week: Plans for Documenting Children's Development, Fifth Edition. USA: Wadsworth, Cengage Learning.

Arends, Richard I. (2012). Learning to Teach, Ninth Edition. USA: Pearson Education, Inc.

Babkie, Andrea M. \& Provost, Mary C. (2004). Teacher as Researcher. Intervention in School and Clinic, May 2004 Vol. 39 No. 5. Journals.sagepub.com/doi/ pdf/10.1177/10534512040390050201 Hal: 260-268 diakses 20 Mei 2015.

Dewey, John. (1929). The Sources of a Science of Education, USA: Horace Liverigth.

Elliott, John (2001). Action Research for Education Change. USA: Open University Press.

Ghaye, Tony. (2011). Teaching and Learning Through Reflective Practice: A Practical Guide for Positive Action, Second Edition. USA: Routledge.

Hill, Susan. (2010). The Millennium Generation: Teacher-researchers Exploring New Forms of Literacy. Journal of Early Childhood Literacy. September 2010. Vol. 10 No. 3 pp. 314-340.

James, E. Alana, Milenkiewicz, Margaret T. dan Bucknam, Alan. (2008). Participatory Action Research for Educational Leadership: Using Data-Driven Decision Making to Improve Schools. USA: SAGE Publications.

Lougran, John. (2010). What Expert Teachers do: Enhancing Professional Knowledge for Classroom Practice. Australia: Allen \& Unwin.

McGregor, Debra dan Cartwright, Lesley. (2011). Developing Reflective Practice: A guide for beginning teachers. USA: Open University Press.

McKernan, James. (2008). Curriculum and Imagination: Process Theory, Pedagogy, and Action Research. USA: Routledge.

Morgan, Jill dan Ashbaker, Betty Y. (2009). Supporting and Supervising Your Teaching Assistant. USA: Continuum International Publishing Group. 